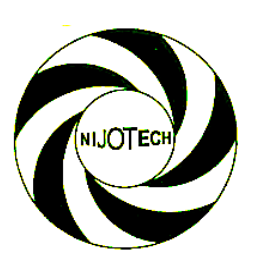

Nigerian Journal of Technology (NIJOTECH)

Vol. 38, No. 3, July 2019, pp. 660 - 667

Copyright@ Faculty of Engineering, University of Nigeria, Nsukka,

Print ISSN: 0331-8443, Electronic ISSN: 2467-8821

www.nijotech.com

http://dx.doi.org/10.4314/njt.v38i3.17

\title{
CHEMICAL, MINERALOGICAL AND PETROLOGICAL CHARACTERIZATION OF GYAZA IRON ORE DEPOSIT, KATSINA STATE, NIGERIA
}

\author{
D. G. Thomas ${ }^{1,}{ }^{*}$, F. Asuke ${ }^{2}$, S. A. Yaro ${ }^{3}$ and S. M. Adams ${ }^{4}$ \\ 1, 2, 3, Dept. Of Met. And Materials Engineering, Ahmadu Bello Univ., Zaria, Kaduna State, NigeriA \\ 4, Dept. of Met. AND Materials Engineering, University of Nigeria, NsuKKa, ENUGu State, NIGERIA \\ E-mail addresses: ${ }^{1}$ dungkathomas@gmail.com, ${ }^{2}$ asukef@yahoo.com; ${ }^{3}$ yaroaliyu@yahoo.com; \\ ${ }^{4}$ sani.adam@unn.edu.ng
}

\begin{abstract}
Chemical, mineralogical and petrological characterization of Gyaza iron ore deposit, Katsina State, Nigeria was carried out. The ore sample was sourced from Gyaza village, Kankiya Local Government Areas of Katsina State and comminuted using laboratory jaw crusher and pulverizing machines respectively. The comminuted sample was analyzed using XRF, XRD, SEM and OPM. The XRF result revealed that the ore contained $0.17 \% \mathrm{P}, 0.02 \% \mathrm{~K}, 0.23 \% \mathrm{Ca}, 0.11 \% \mathrm{Mn}, 36.17 \% \mathrm{Fe}, 0.08 \% \mathrm{Ba}$, $0.18 \% \mathrm{Mg}, 1.10 \% \mathrm{Al}$ and $17.21 \%$ Si. The XRD result revealed that the complex mineral phases of the ore are Aluminum-Silicate-Hydroxide-Hydrate $\left(\mathrm{Al}_{2} \mathrm{Si}_{2} \mathrm{O}_{5}(\mathrm{OH})_{4.2} \mathrm{H}_{2} \mathrm{O}\right)$, Chrysotile ( $\mathrm{Mg}_{3}\left[\mathrm{Si}_{2}-\right.$ $\left.\left.\mathrm{xO}_{5}\right](\mathrm{OH})_{4-4 x}\right)_{1} \quad$ Magnesium-Aluminum-Silicate-Hydroxide-Hydrate $\left((\mathrm{Mg}, \mathrm{Al}) \mathrm{g} \quad\left(\mathrm{Si}_{1} \mathrm{Al}\right)_{8} \mathrm{O}_{20}\right.$

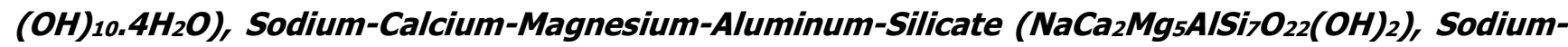
Iron-Silicate-hydroxide (( $\left.\mathrm{Na}, \mathrm{Ca}) 2(\mathrm{Fe}, \mathrm{Mn}) \mathrm{Fe}_{2}(\mathrm{Si}, \mathrm{Al}){ }_{8} \mathrm{O}_{22}(\mathrm{OH})\right)$, Orthoclase (KAlSi $\left.{ }_{3} \mathrm{O}_{8}\right)$ and SodiumCalcium-Iron-Aluminum-Silicate-Hydrate (NaCa $\left.{ }_{2} \mathrm{Fe}_{4} \mathrm{AlSi}_{6} \mathrm{Al}_{2} \mathrm{O}_{22}(\mathrm{OH})_{2}\right)$. And the single mineral phases are Quartz ( $\left.\mathrm{SiO}_{2}\right)$, Hematite $\left(\mathrm{Fe}_{2} \mathrm{O}_{3}\right)$ and Goethite $\left(\mathrm{Fe}_{2} \mathrm{O}_{3} \mathrm{H}_{2} \mathrm{O}\right)$ which are also the major minerals phases. The SEM and petrological results revealed that the ore matrix is an assemblage of inter-layered different minerals crystals with different shapes, sizes and angles of orientations and separated by grain boundaries.
\end{abstract}

Keywords: Chemical, Mineralogical, Petrological, Characterization, Gyaza, Iron ore.

\section{INTRODUCTION}

The utilization of mineral ore deposits are the basic foundation for the techno-economical development of any country. A country that neglects its mineral deposits endowments will ever remain undeveloped and technologically backward in its national development plans [1].

Today some research institutions and individuals are working hard to bring to bear the enormous qualities, quantities and areas of application of locally sourced and characterized mineral ores as an alternative to the nation dependence on the importation of alloying elements and other mineral related materials for the local nation's iron and steel plants [1].

\footnotetext{
* Corresponding author, tel: +234 - 703- 289- 1919
}

Solid minerals development plays very significant role in the economies of both the mineral-rich and consuming countries. While the few developed mineral-producing countries such as Australia, Canada, Germany and United States of America (USA) have benefited greatly from mining, mineral processing and utilization, only a handful of their counterparts in the developing regions have succeeded in transforming the revenues accrued from mining into concrete and demonstrable sustainable development [2].

In exploitation of any mineral, it is important to understand the main inherent properties and composition which determine their behaviour during processing. Hence, the characteristics of minerals also 
often determine their economical aspect of commercial exploitation of their deposits. A country is sometime regarded as industrially developed when it has substantial iron and steel production capacity [3]. Today demand for mineral commodities has risen over the last few years largely due to the growth of the emerging economies of Asia, thus raising the global mineral commodity prices, with worldwide increase in exploration activities [4]. This quest for minerals places high demand for iron minerals worldwide. Iron ores occur in igneous, metamorphic (transformed), or sedimentary rocks in a variety of geologic environments. Nigeria as a country has over Three (3) billion tonnes of iron ores deposits in estimated reserve and despite these abundant deposits the nation has little or no data on the characteristics of these deposits. Hence, their exploitation for iron and steel making is impaired and much foreign exchange is expended on the importation of iron and steel materials that can be locally sourced and produced in the nation's iron and steel plants. Therefore, through this research work the characteristics of the Gyaza iron ore will be made available and added to database of the nation's iron ores resources. It is on the basis of the mentioned factors that prompt this research on chemical, mineralogical and petrological characterization of Gyaza iron ore deposit with the aim of determining its usability in the nation's iron and steel industries and diversification of the economy.

\section{REVIEW OF SOME RELATED WORKS ON CHEMICAL AND MINERALOGICAL CHARACTERISTIC OF IRON ORE DEPOSIT IN NIGERIA}

Nigerian iron ore deposits are distributed mostly across every state of the nation but are predominantly found along the Benue and Niger troughs. Tables 1.0and 2.0 present some of the Nigerian iron ore deposits, their locations and chemical compositions.

Table 1: Some of Nigerian iron ores deposits and their locations Source: [5]

\begin{tabular}{|c|c|c|c|c|}
\hline S/No. & Deposits & Locations & Iron Content (\%) & Estimated Reserve in Tonnes \\
\hline 1. & Itakpe & Kogi & $36-88$ & 200-300 million \\
\hline 2. & Ochokochoko & Kogi & & 12-14 million \\
\hline 3. & Ajabanoko & Kogi & 40 & 60 million \\
\hline 4. & Agbadookudu & Kogi & $38-48$ & 60 million \\
\hline 5. & Akoina & Kogi & & Under investigation \\
\hline 6. & Tajimi & Kogi & & 200 million \\
\hline 7. & Ero & Kogi & & - \\
\hline 8. & Ebiya & Kogi & & - \\
\hline 9. & Obajana & Kogi & & - \\
\hline 10. & KotonKarfe & Kogi & $43-53$ & 850 million \\
\hline 11. & BassaNge (Egenji Ate) & Kogi & $43-49$ & 400 million \\
\hline 12. & Kakun (Kabba) & Kogi & & - \\
\hline 13. & Ubo-Toso & Kogi/Edo & & - \\
\hline 14. & Akunu (Ikare) & Ondo & & - \\
\hline 15. & Gujeni & Kaduna & & - \\
\hline 16. & Kagara (Kubacha) & Kaduna & & - \\
\hline 17. & BirniGwari & Kaduna & & - \\
\hline 18. & Toto Muro & Nasarawa & & 3.8 million \\
\hline 19. & Rishi & Bauchi & $10-19$ & - \\
\hline 20. & Ayi Wawa & Bauchi & & - \\
\hline 21. & Karfe & Borno & & - \\
\hline 22. & Gamawa & Bauchi & & - \\
\hline 23. & Dakin Gari & Kebbi & & - \\
\hline 24. & Nsude & Enugu & & - \\
\hline
\end{tabular}


Chemical, Mineralogical and Petrological Characterization of Gyaza Iron Ore Deposite, Katsina State,... D. G. Thomas, et al.

\begin{tabular}{lllll}
\hline S/No. & Deposits & Locations & Iron Content $(\%)$ & Estimated Reserve in Tonnes \\
\hline 25. & Ameki/Ohafia & Abia & & - \\
26. & Veketuwo & Plateau & & - \\
27. & Agbaja & Kogi & & Over one billion \\
28. & Nsuge Hill & Anambra & $43-50$ & 3.8 million \\
29. & Bakingari & Sokoto & 37 & \\
\hline
\end{tabular}

Table 2: Chemical Composition of Some Nigerian Iron Ore Deposits Sources: $[6,7]$

\begin{tabular}{lllllllllll}
\hline Deposit & $\%_{2} \mathrm{O}$ & $\% \mathrm{CaO}$ & $\% \mathrm{TiO}_{2}$ & $\% \mathrm{MnO}$ & $\% \mathrm{Fe}$ & $\% \mathrm{MgO}$ & $\% \mathrm{Al}_{2} \mathrm{O}_{3}$ & $\% \mathrm{SiO}_{2}$ & $\%_{2} \mathrm{O}_{5}$ & $\% \mathrm{~S}$ \\
\hline Chokochoko & 0.53 & 0.15 & 0.16 & 0.08 & 34.45 & 0.18 & 9.67 & 51.07 & 0.02 & 0.007 \\
Agbado-Okudu & 0.04 & 0.72 & 0.37 & 0.14 & 47.80 & 0.38 & 9.60 & 10.89 & 2.08 & 0.12 \\
Ajagbaoko & 0.26 & 0.21 & $\mathrm{Trace}$ & 0.01 & 37.22 & 0.15 & 3.39 & 46.50 & 0.01 & 0.03 \\
Bassa-Nge & 0.02 & 0.17 & 0.17 & 0.13 & 46.90 & 0.40 & 8.28 & 8.28 & 1.45 & 0.05 \\
\hline
\end{tabular}

\subsection{Review of some Related Works on Chemical and Mineralogical Characterization of Iron Ores Deposits}

Salahu, et al [7], worked on the characterization of Gujeni iron ore, Kagarako Local Government Area, of Kaduna State and reported that: the iron ore contains mainly $48.6 \% \mathrm{Fe}, 0.2 \mathrm{wt} . \% \mathrm{Mn}, 12.01 \% \mathrm{Ti}, 2.06 \% \mathrm{P}$, $0.2 \% \mathrm{~S}, \quad 6.0 \% \mathrm{Si}, 4.4 \% \mathrm{Al}$; mineralogical analysis revealed that the ore is predominantly hematite, goethite, rutile, aluminite and other associated minerals like silica, phosphorus, sulphur, zincite and zirconite which can be separated during mineral processing. The SEM analysis results revealed that the iron minerals are separated from other minerals contained in the ore by smooth boundaries that may make it easy to liberate from other associated minerals. The petrological analysis results revealed that the structures of the iron bearing minerals are in form of plates and river lines, which are the characteristics of hematite and goethite.

Ahmed et al [8], worked on the Jaruwa Iron deposit and reported that ore is a rich hematite ore intercalated with kaolinitic clays covered by lateritic overburden and hosted mainly by amphibolites and meta-sediments. Generally, based on the analysis of the raw $\mathrm{Fe}$ content, gangue $\left(\mathrm{SiO}_{2}+\mathrm{Al}_{2} \mathrm{O}_{3}\right)$, contaminants ( $\mathrm{P}$ and $\mathrm{S}$ ) and other impurities, he concluded that the iron ore from Jaruwa has met the requirements for profitable exploitation and exportation, and can serve well as a good raw material for iron production.

Adedeji and Sala [9], worked and reported that Mozambique Belt, Ikutha area in Kenya's iron ore deposits has characteristics as follows:

i. The ore deposits are fairly rich in magnetite and apatite, although other minerals such as amphiboles and pyroxenes are found associated with them. Some of the rocks have high iron values, some as high as over $90 \%$. This iron can therefore be mined economically. Apatite varies between $4 \mathrm{wt} . \%$ and $20 \%$. Many of the magnetite rich rocks were found to have high iron oxide levels, some more than $70 \%$. These include disseminated iron ore, thin ore veins and $3.5 \mathrm{~m}$ of weathered hornblende/pyroxene gneisses.

ii. It was noted that for samples with more than $40 \%$ $\mathrm{Fe}_{2} \mathrm{O}_{3}$, phosphate values were ranging from $1.9 \%$ $-6 \%$, with averages of $4.4 \%$. These samples have little or no water at all, i.e. no loss of ignition.

[10], worked and reported that the characteristics of Itakpe, Agbaja and Corby (Nigerian) iron ores as:

i. Itakpe ore is a rich hematite ore in which some hematite forms an intergrowth with magnetite. The main impurity is silica. Following liberation by mechanical crushing and physical separation of the quartz, the Itakpe ore is suitable as a feedstock to one of the direct reduction methods of iron making. The ore is typical of one formed by magmatic segregation.

ii. Agbaja ore is an acidic pisolitic ore consisting of goethite, magnetite and major amounts of aluminous and siliceous minerals. It cannot be used directly in a blast furnace or other reduction process without further treatment, e.g. sintering, pelletizing or briquetting.

iii. Corby ore is confirmed as a basic pisolitic carbonate ore with a basicity of $\sim 0.9$. Both Agbaja and Corby ores are lean and of sedimentary origin.

iv. Reduction studies of the three ores indicate that Itakpe ore is the most reducible in both hydrogen and carbon monoxide, whereas Corby ore is the least reducible within the temperature range 800 $1000^{\circ} \mathrm{C}$. At $1100^{\circ} \mathrm{C}$ Agbaja ore is the least 
reducible because sintering of the ore prevents access of the reducing agent.

Asuke [11], worked on dephosphorization of KotonKarfe iron ore by acidic leaching and reported that the phosphorus content can be reduced by acidic leaching technique.

Thomas and Yaro [12], worked on Koton-Karfe iron ore and concluded that the ore has iron content of $43.34 \%$ with low silica content of $10.14 \%$ and the major mineral phases of the ore are magnetite, siderite and goethite. The work index of the KotonKarfe iron ore was found to be $11.33 \mathrm{kWh} / \mathrm{t}$.

Agava [13], worked on Agbado-Okudu iron ore and reported that the ore contained $38.82 \% \mathrm{Fe}$ and the mineralogical analysis of the revealed magnetite and hematite as the major phases of the ore.

Furthermore, to the best of our knowledge no available data and work that has been carried out on this iron ore reason been that is a newly discovered iron ore deposit awaiting detail exploration and possibly exploitation.

\section{MATERIALS AND METHODS}

\subsection{Materials and Equipment}

$5 \mathrm{~kg}$ of iron ore sample, $\mathrm{X}$-ray fluorescence (XRF), Xray diffractometer (XRD) Machine Scanning electron microscope (SEM), Optical microscope (OPM) Sledge hammer, Jaw crusher

\subsection{Location of Gyaza Iron Ore Deposit}

Gyaza iron ore deposit which is popularly known as "Tsaunin-Kudi" (meaning Mountain of wealth) is located in UnguwanJAkada eastern axis of Gyaza village in Kankiya Local Government Area of Katsina State, Nigeria. Its headquarters is located in Kankiya town north of the area on the A9 highway at $12^{\circ} 32^{\prime} 57^{\prime \prime} \mathrm{N} 7{ }^{\circ} 49^{\prime} 31^{\prime \prime} \mathrm{E} / 12.54917^{\circ} \mathrm{N} 7.82528^{\circ} \mathrm{E}$

\subsection{Sample Collection}

Plates 1,2 , and 3 are the photographs of the activities that took place during the sampling of the iron ore. Fifty (50) $\mathrm{kg}$ of the ore sample was sourced from three (3) different points 3meters apart and 1-meter depth from each points of the ore deposit.

\subsection{Sample Preparation}

Sample preparation involves comminution which consists of crushing and grinding process. The lump sizes of the ore sample were reduced to the sizes that can be accepted by the crusher using sledge hammer. The sample was crushed using jaw crusher and pulverized using ball mill. The harmonized sample of the ore was quartered and used for further analyses.

\subsection{Chemical Analysis of the ore using X-ray Fluorescence (XRF)}

The chemical analysis of the ore sample was carried out using explorer version EX-7000 X-ray spectrometer, an energy dispersive microprocessor controlled analytical instrument designed for the detection and measurement of elements in a (solids, powders and liquids). The system is controlled by a PC running the dedicated mini analytical software. The pellet made out of the sample to be analyzed was loaded in the sample chamber of the spectrometer and voltage (45kV maximum) and a current $(45 \mu \mathrm{A})$ maximum) was applied to produce the $x$-rays to excite the sample for a preset time (30sec in this case). The spectrum from the sample was then analyzed to determine the concentration of the element in the sample.

\subsection{Mineralogical Analysis of the ore using X-ray Diffraction (XRD)}

The mineralogical analysis of the ore was carried out using XRD Schimadzu 6000 Model. The sample was placed in a sample holder on the gionometer of the XRD machine. The chamber hosting the $x$-ray source and sample was then closed for the analysis of the sample to take place. Using ICCD soft-ware run by a PC attached to the XRD Schimadzu 6000 Model the mineral phases of the ore sample was determined.

\subsection{Mineral Particle Size analysis of the ore using Scanning Electron Microscopy (SEM)}

The analysis was carried out using the field emission Scanning Electron Microscopy (SEM) equipped with EDS. A small amount of the sample powder was taken and placed on the sample holder and placed inside the machine and waited for the machine to be ready.

A vacuum was built in the sample chamber, the sample was then irradiated to generate emission from which micrograph of the sample was produced. Using the SEM fiber chart analysis soft-ware run by a PC attached to the SEM machine, the particle size of the various mineral grains of the ore sample was determined Inform of a bar chart. 

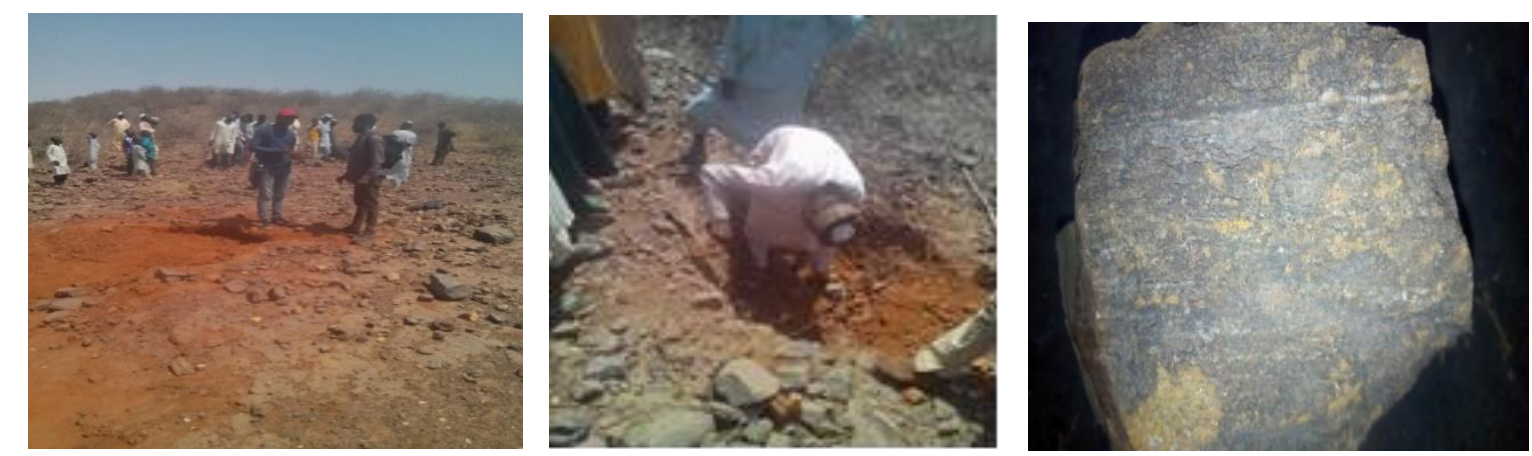

Plate 1: The iron ore outcrop Plate 2: Sourcing of samples

Plate 3: Sample of Gyaza Iron Ore

\subsection{Petrological analysis of the ore using Optical Microscopy (OPM) with built-in camera}

The petrological analysis using OPM was carried out. An area measuring $1 \mathrm{~cm}^{2}$ of the iron ore sample was cut using Laboratory cutting machine. The sample was ground using silicon carbide emery paper number 220, 320, 400 and 600 with proper rinsing with water. Polishing of the sample was carried out on a rotating cloth pad machine using aluminum oxide powder until mirror like surface was obtained. The polished sample was examined under a combination of plane and cross-polarized light using NJF-120A optical petrographic microscope with built-in camera. The mineral identification colour matched of the sample was carried out using a standard chart Atlas of rocks and minerals [14].

\section{RESULTS AND DISCUSSION}

\subsection{Chemical Composition of Gyaza Iron Ore}

Table 3 presents the result of the chemical analysis of the ore sample using XFR. The result presented in Table 3.0 revealed that the ore contains $0.17 \% \mathrm{P}$, $0.02 \% \mathrm{~K}, 0.23 \% \mathrm{Ca}, 0.11 \% \mathrm{Mn}, 36.17 \% \mathrm{Fe}, 0.08 \% \mathrm{Ba}$, $0.18 \% \mathrm{Mg}, 1.10 \% \mathrm{Al}$ and $17.21 \% \mathrm{Si}$. Other elements associated with ore are in traces. Furthermore, when comparing the result obtained in Table 3.0 to others cited in Table 2.0 of this work. It can be observed that the iron content of the ore is higher when compared to $34.45 \% \mathrm{Fe}$ of Chokochoko, almost similar in content to that of Ajabanoko (37.22\% Fe) but lower than that of Agbado-Okudu (47.80\%Fe) and Bassa-Nge $(46.90 \% \mathrm{Fe})$. The aluminum, magnesium and calcium contents of the ore compared favorably with that reported by [6] in Table 2.0.

The silicon content of the ore $17.21 \% \mathrm{Si}\left(56.56 \% \mathrm{SiO}_{2}\right)$ is moderately higher when compared to those cited in Table 2.0. Despite the moderately high silica content and other associated minerals of the ore, their presence cannot stop the utilization of the ore. Since the silica and other associated minerals can be removed during beneficiation. Hence the Gyaza iron ore can be said to be another potential source of iron and other minerals that can be beneficiated and utilize in Ajaokuta for iron and steel making.

\subsection{Mineralogical Composition of Gyaza Iron Ore}

Table 4 presents the XRD analysis result of the ore sample and the identified mineral phases contained in the ore matrix. The XRD result presented in Table 4 revealed that the ore contains both single and complex mineral phases in its matrix. The complex mineral phases are Aluminum-Silicate-Hydroxide -Hydrate $\left(\mathrm{Al}_{2} \mathrm{Si}_{2} \mathrm{O}_{5}(\mathrm{OH})_{4} .2 \mathrm{H}_{2} \mathrm{O}\right)$, Chrysotile $\left(\mathrm{Mg}_{3}\left[\mathrm{Si}_{2}-\mathrm{XO}_{5}\right](\mathrm{OH})_{4}\right.$ 4x), Magnesium-Aluminum-Silicate-Hydroxide-Hydrate

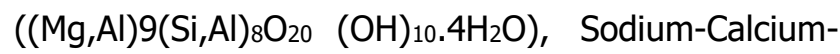
Magnesium-Aluminum-Silicate $\quad\left(\mathrm{NaCa}_{2} \mathrm{Mg}_{5} \mathrm{AlSi}_{7} \mathrm{O}_{22}\right.$ $\left.(\mathrm{OH})_{2}\right)_{1}$ Sodium-Iron-Silicate-Hydroxide $\quad((\mathrm{Na}, \mathrm{Ca}) 2$ $\left.(\mathrm{Fe}, \mathrm{Mn}) 3 \mathrm{Fe}_{2}(\mathrm{Si}, \mathrm{Al})_{8} \mathrm{O}_{22}(\mathrm{OH})\right)$, Orthoclase $\left(\mathrm{KAlSi}_{3} \mathrm{O}_{8}\right)$ and Sodium-Calcium-Iron-Aluminum-Silicate-Hydrate ( $\mathrm{NaCa}_{2} \mathrm{Fe}_{4} \mathrm{AlSi}_{6} \mathrm{Al}_{2} \mathrm{O}_{22}(\mathrm{OH})_{2}$ ).

Table 3: chemical analysis of the ore using XRF

\begin{tabular}{ll}
\hline Element & $\%$ \\
\hline $\mathrm{Mg}$ & 0.1839 \\
$\mathrm{Al}$ & 1.1023 \\
$\mathrm{Si}$ & 17.2123 \\
$\mathrm{P}$ & 0.1663 \\
$\mathrm{~K}$ & 0.0202 \\
$\mathrm{Ca}$ & 0.2263 \\
$\mathrm{Mn}$ & 0.1099 \\
$\mathrm{Fe}$ & 36.1694 \\
$\mathrm{Ba}$ & 0.0478 \\
$\mathrm{~PB}$ & 0.0010 \\
\hline
\end{tabular}


Chemical, Mineralogical and Petrological Characterization of Gyaza Iron Ore Deposite, Katsina State,... D. G. Thomas, et al.

Table 4: XRD Analysis Result of Gyaza iron ore sample

\begin{tabular}{|c|c|c|c|}
\hline Card no & Mineral name & Chemical name & Chemical formula \\
\hline $29-1489$ & & Aluminum Silicate Hydroxide Hydrate & $\mathrm{Al}_{2} \mathrm{Si}_{2} \mathrm{O}_{5}(\mathrm{OH})_{4} \cdot 2 \mathrm{H}_{2} \mathrm{O}$ \\
\hline $\begin{array}{l}25-0645 \\
23-1405\end{array}$ & Chrysotile & $\begin{array}{l}\text { Magnesium Silicate Hydroxide } \\
\text { Sodium Calcium Magnesium Aluminum } \\
\text { Silicate }\end{array}$ & $\begin{array}{l}\mathrm{Mg}_{3}\left[\mathrm{Si}_{2}-\mathrm{xO}_{5}\right](\mathrm{OH})_{4-4 \mathrm{x}} \\
\mathrm{NaCa}_{2} \mathrm{Mg}_{5} \mathrm{AlSi}_{7} \mathrm{O}_{22}(\mathrm{OH})_{2}\end{array}$ \\
\hline $\begin{array}{l}33-0664 \\
31-0794\end{array}$ & Hematite & $\begin{array}{l}\text { Iron Oxide } \\
\text { Magnesium Aluminum Silicate Hydroxide } \\
\text { Hydrate }\end{array}$ & $\begin{array}{l}\mathrm{Fe}_{2} \mathrm{O}_{3} \\
(\mathrm{Mg}, \mathrm{Al}) 9(\mathrm{Si}, \mathrm{Al})_{8} \mathrm{O}_{20}(\mathrm{OH})_{10} .4 \mathrm{H}_{2} \mathrm{O}\end{array}$ \\
\hline $\begin{array}{l}13-0092 \\
19-1061\end{array}$ & Goethite & $\begin{array}{l}\text { Iron Oxide Hydrate } \\
\text { Sodium Iron Silicate Hydroxide }\end{array}$ & $\begin{array}{l}\mathrm{Fe}_{2} \mathrm{O}_{3} \cdot \mathrm{H}_{2} \mathrm{O} \\
(\mathrm{Na}, \mathrm{Ca}) 2(\mathrm{Fe}, \mathrm{Mn}) 3 \mathrm{Fe}_{2}(\mathrm{Si}, \\
\mathrm{Al})_{8} \mathrm{O}_{22}(\mathrm{OH})\end{array}$ \\
\hline $46-1045$ & Quartz & Silicon Oxide & $\mathrm{SiO}_{2}$ \\
\hline $31-0966$ & Orthoclase & Potassium Aluminum Silicate & $\mathrm{KAISi}_{3} \mathrm{O}_{8}$ \\
\hline $26-1372$ & & $\begin{array}{l}\text { Sodium Calcium Iron Aluminum Silicate } \\
\text { Hydrate }\end{array}$ & $\mathrm{NaCa}_{2} \mathrm{Fe}_{4} \mathrm{AlSi}_{6} \mathrm{Al}_{2} \mathrm{O}_{22}(\mathrm{OH})_{2}$ \\
\hline
\end{tabular}

While the single mineral phases of the orematrixare Hematite $\left(\mathrm{Fe}_{2} \mathrm{O}_{3}\right)$, Goethite $\left(\mathrm{Fe}_{2} \mathrm{O}_{3} \cdot \mathrm{H}_{2} \mathrm{O}\right)$ and Quartz $\left(\mathrm{SiO}_{2}\right)$. Also, from the result it can be observed that the major mineral phases of the ore are predominantly goethite, hematite and quartz while the other iron bearing and associated complex mineral phases are minors. This trend of mineral assemblage can be attributed to the differential mineralization of the ore deposit that may have been caused by the geochemical tectonic activity of the ore deposit during its formation. The revealed mineral phases of the iron ore seem to agree with similar observations made and reported by $[3,7,15]$ on some iron ores.

\subsection{SEM Analysis Result of the Iron Ore Sample}

Plates 4 and 5 are the SEM photomicrographs of the ore sample at $1000 \mu \mathrm{m}$ (coarse) and $100 \mu \mathrm{m}$ (semifine) particle sizes at low and high magnifications. Figure 1shows the EDS pattern result of the ore sample.

From the SEM micrograph shown in Plate. 4 the result revealed that the ore consists of various mineral crystals. At higher magnification as shown in Plate.5the various mineral crystals are assemblage of interlayer mineral crystal planes separated by slipboundaries as it can be observed. Some of minerals are dark, while others white and grey in colours. The mineral crystals vary in sizes, shapes and angles of orientations. The demarcation of the various mineral crystals by slip-boundaries indicates that the minerals can be fragmented during comminution and thus be liberated from each other. The EDS result of the ore in Figure 1 revealed that iron (Fe) has the highest peak count of 27975 at $6.08 \mathrm{eV}$ when compared to other elements like $\mathrm{Al}, \mathrm{Ca}, \mathrm{K}, \mathrm{Mg}$, contained in the ore with peaks counts less than 3730 in ranges of 0 $4.29 \mathrm{eV}$. This trend indicates that the ore is predominantly rich in iron (Fe). Figure 2 shows the fibreSEM metric measurement analysis result of the ore sample. The result revealed that, the particle size fractions of the various minerals range from 6.62 to $51.91 \mu$ mand indication that the mineral fractions of the ore are in semi-coarse to fine particle sizes form. Furthermore, the EDS result also confirmed and correlates the XRD result of the ore where its revealed that, the predominantly mineral phases of the ore are goethite and hematite which are the primary sources of the iron (Fe) in the ore matrix.

\subsection{Petrological Composition of Gyaza Iron Ore} Plates 6 and 7 are photomicrographs showing the petrological composition of the Gyaza iron ore under un-polarized and polarized light sourced. From the photomicrographs result of Plates 6 and 7, it can be observed that the matrix of the ore is made up of various minerals grains that varies in sizes, shapes and colours. The prominent colours are white, grey and black (dark). [3], [7] and [14] reported that most dark (black) colours minerals in iron matrix are usually silica, white colours are hematite and grey colours are goethite depending on the formation of the iron ore. 


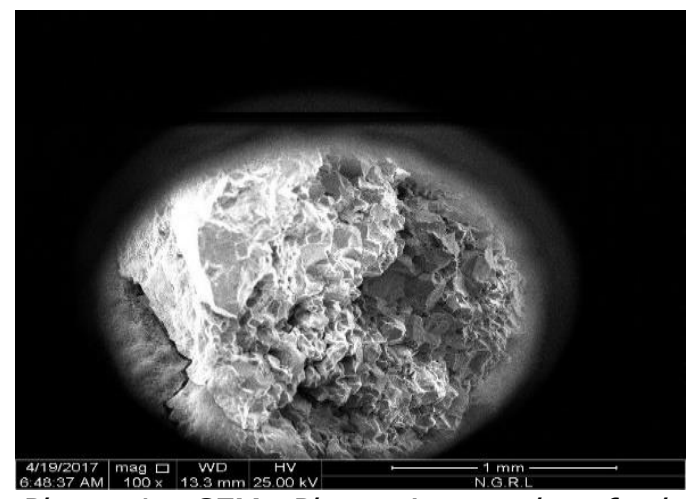

Plate 4: SEM Photomicrograph of the ore at $1000 \mu \mathrm{m}(\mathrm{x} 100)$ at $100 \mu \mathrm{m}(\mathrm{x1284})$

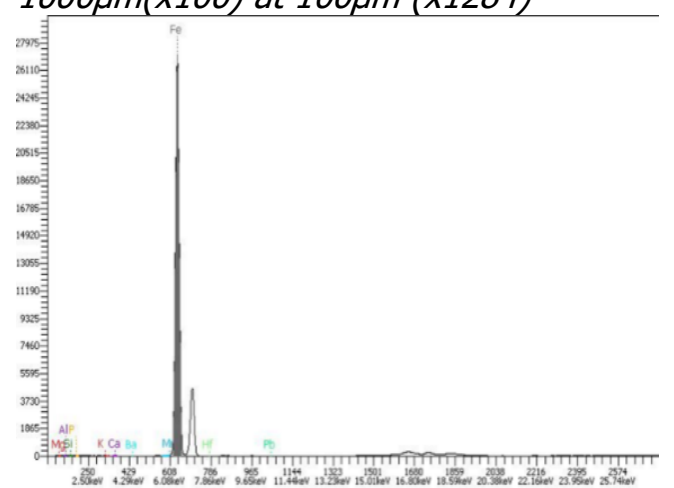

Figure. 1: EDS pattern of Gyaza iron ore sample

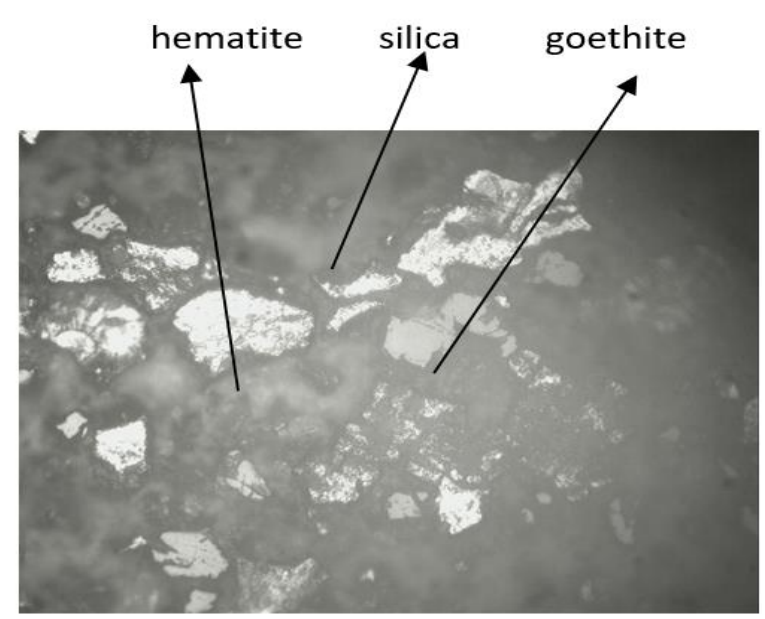

Plate 6: OPM Photomicrograph of the ore sample at x100 with un-polarized light

However similar colours were observed for the Gyaza iron ore as white - hematite $\left(\mathrm{Fe}_{2} \mathrm{O}_{3}\right)$, grey - goethite $\left(\mathrm{Fe}_{2} \mathrm{O}_{3} \cdot \mathrm{H}_{2} \mathrm{O}\right)$ and dark (black) - silica $\left(\mathrm{SiO}_{2}\right)$. Furthermore, the minerals grains are separated by grain boundaries and indications that the minerals can be fragmented during the process of comminution and be liberated.

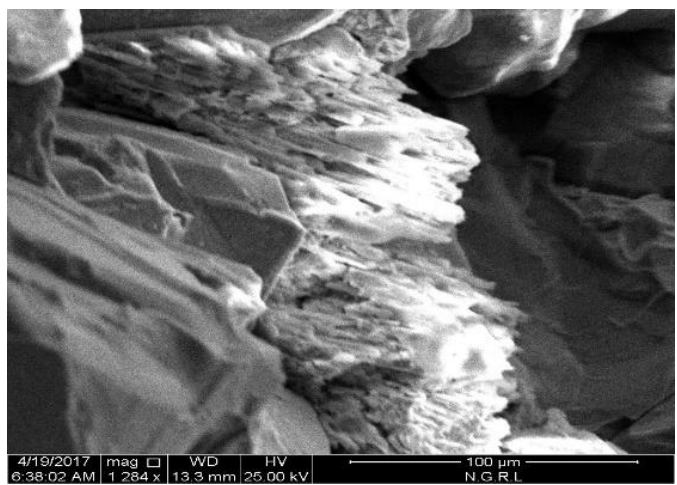

Plate 5: SEM Photomicrograph of the ore

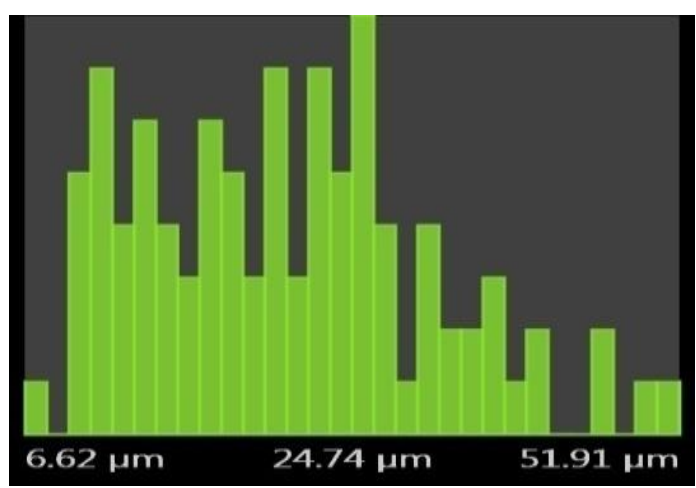

Figure 2: SEM fibre metric measurement of the particle sizes of the ore sample.

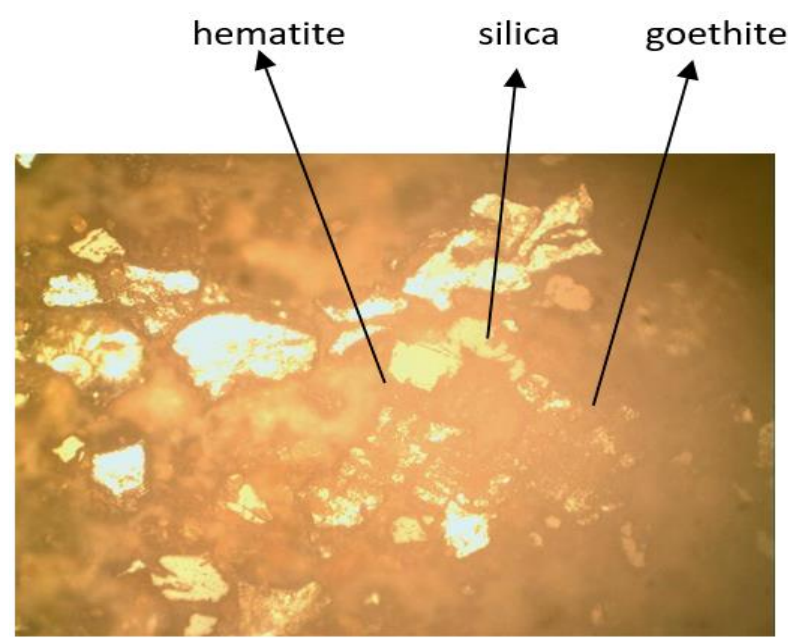

Plate 7: OPM Photomicrograph of the ore Sampleatx100with crossed polarized light

\section{CONCLUSION AND RECOMMENDATIONS \\ 5.1 Conclusion}

The Gyaza iron deposit is a rich hematite and goethite ore intercalated with alumina, silica, chrysotile and orthoclase. The chemical analysis revealed that the iron ore contains mainly $0.17 \% \mathrm{P}, 0.02 \% \mathrm{~K}, 0.23 \% \mathrm{Ca}$, $0.11 \% \mathrm{Mn}, 36.17 \% \mathrm{Fe}, 0.08 \% \mathrm{Ba}, 0.18 \% \mathrm{Mg}, 1.10 \% \mathrm{Al}$ and $17.21 \% \mathrm{Si}$. The mineralogical analysis of the ore revealed that the iron ore is predominantly hematite, 
goethite, alumina and other associated minerals like quartz, orthoclase and chrysotile which can be separated during mineral processing. The SEM analysis results revealed that the iron minerals are separated from other minerals contained in the ore by boundaries that may make it easy for the valuable minerals to be fragmented during comminution and be liberated from other associated minerals. Also, the fibre SEM analysis of the ore sample result also revealed that the particle size fractions of the various minerals range from 6.62 to $51.91 \mu \mathrm{m}$. The petrological analysis results revealed that the textures of the iron bearing minerals are in form of plates and river lines, which are the characteristics of hematite and goethite. The dark areas are mixture of goethite and silicate minerals while the white area is hematite. Generally, based on the analysis of the $\mathrm{Fe}$ content, gangue $\left(\mathrm{SiO}_{2}+\mathrm{Al}_{2} \mathrm{O}_{3}\right)$, contaminant $(\mathrm{P})$ and other impurities, the ore can be classified as a lowgrade iron ore that can be profitable exploited as raw material for iron and steel making in the nation's iron and steel plants after beneficiation.

\subsection{Recommendations}

i. Tests for the amenability to different concentration techniques of the iron ore should be carried out.

ii. The effect of pre-thermal treatments on the ore should be carried out.

iii. The particle size/assay analysis of the ore should be carried out to ascertain its liberation size.

iv. The energy and the work index of the ore should be carried out to establish the parameters.

\section{REFERENCES}

[1] Thomas, D. G., Asuke, F. and Yaro, S. A. "Viability of Some Nigerian Mineral Ores as Sources of Fuels and Alloying Elements for Armaments Production", Nigerian Metallurgical Society, $32^{\text {nd }}$ Conference and Annual General Meeting Book of Proceeding, Kaduna, October 26-29, 2016, pp21-34.

[2] NEITI, "An Evaluation of the Nature and Character of the Nigeria Extractive Industries", A Publication of Nigeria Extractive Industries Transparency Initiative (NEITI), Vol. 2, 2010, pp 1-5.

[3] Thomas, D. G. and Yaro, S. A. "Chemical and Mineralogical Characteristics of Koton-Karfe Iron
Ore", Journal of Engineering and Technology (Jet) Bayero University, Kano, Vol. 4, No.1, 2009, pp 6571.

[4] Masok, Y. S. "Characterization and Beneficiation of Zurak Lead-Zinc Ore Deposit in Plateau State, Nigeria", Department of Metallurgical and Materials Engineering, Ahmadu Bello University, Zaria. M.Sc. Thesis, Unpublished. 2015.

[5] GSN. Annual Report of the Geological Survey of Nigeria, 1987, Pp 26-27.

[6] RMRDC, "Industrial Raw Materials", Journal of the Raw Material Research and Development Council. Abuja, 2000, pp. 3 - 4.

[7] Salawu, A. O., Yaro, S. A. and Thomas, D. G. "Determination of Chemical Composition and Liberation Size of Gujeni Iron Ore Deposit, Kaduna State, Nigeria", Nigerian Mining Journal, A Publication of Nigerian Society of Mining Engineers, Vol.13, No.1, 2015, pp 62-67.

[8] Ahmad, I. H., Umar, S. U., Abdullahi, A. M., and Maude, K. A. "Geochemistry and Economic Potential of Jaruwa Iron Ore, NW- Nigeria", Imperial Journal of Interdisciplinary Research. Vol. 3, Number 3, 2017, pp 1067.

[9] Michael, K. M. "Geochemical Characterization of Iron Ore Deposits of the Mozambique Belt, Ikutha Area in Kenya", Project in Geology Kang'utu University, Kenya, Unpublished, 2008.

[10] Adedeji, F. A. and Sale F. R. "Characterization and Reducibility of Itakpe and Agbaja (Nigeria) iron ore", Journal of Minerals, Vol., 19, 1984, pp 843856.

[11] Asuke, F. "Dephosphorization of Koton-Karfe Iron Ore using Acidic Leaching Technique" Department of Metallurgical and Materials Engineering, Ahmadu Bello University, Zaria. PhD. Dissertation, Unpublished, 2014.

[12]Thomas, D. G. and Yaro, S. A. "Determination of the Work Index of KotonKarfe Iron Ore", Nigerian Society of Mining Engineers (NSME), $10^{\text {th }}$ Annual General Meeting/Conference, Coal City, Enugu State, November, 7 -10, 2007.

[13] Agava, A. A. "Upgrading of Agbado-Okudu iron ore deposit using magnetic separation and shaking table techniques", Department of Metallurgical and Materials Engineering, Ahmadu Bello University. Zaria. M.Sc. Thesis, Unpublished, 2006.

[14] MacKenzie, W. S. and A. E. Adams, A Colour Atlas of Rocks and Minerals, Manson Publishing, Barcelona, Spain, 1995.

[15] Weiss, N. L. SME Mineral Processing Handbook, New York: Society of Mining Engineers, Vol. 2. 1985. 